\title{
Extent of Implementation of Inquiry-based Science Teaching and Learning in Ghanaian Junior High Schools
}

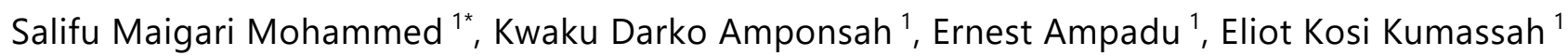 \\ ${ }^{1}$ Department of Teacher Education, School of Education and Leadership, College of Education, University of Ghana, Legon, \\ Accra, GHANA
}

Received 15 March 2020 - Accepted 23 October 2020

\begin{abstract}
The purpose of this study was to investigate the extent of implementation of inquiry-based science teaching and learning in Ghanaian junior high schools. We sampled 503 students, 18 integrated science teachers, and 23 educational administrators from rural and urban areas of four districts and municipalities in the Central Region of Ghana. We used concurrent triangulation mixed methods design to collect quantitative and qualitative data. Validities, reliabilities, credibility, and dependability of the instruments were adequate. Average item means and standard deviations, frequencies, percentages, ANOVAs, Two-way MANOVA, principal component analysis, and Cronbach alphas were calculated. Thematic analysis was also conducted. We found rare implementation of inquiry-based science teaching and learning in the selected Ghanaian junior high schools. We also found significant interaction of school location and school type on the implementation of inquiry-based science instruction. Specifically, we found that codeswitching of English and the local language significantly promoted the implementation of social aspect of inquiry in rural schools. We recommend more reforms in science teaching and learning in Ghanaian junior high schools to be aligned with the features of inquiry. We also recommend that code-switching of English and the local language be actively promoted in schools, especially in rural and public junior high schools.
\end{abstract}

Keywords: inquiry approach, traditional instruction, science teaching and learning, English language learners, code-switching, junior high school

\section{INTRODUCTION}

Decades of traditional instruction is a major contributor to the low scientific literacy in Africa (e.g., Anamuah-Mensah, 2012; Shumba, 1999). In attempts to address the low scientific literacy, inquiry-based science teaching and learning is emphasized as the current curricula rationale for basic science education in many African countries (e.g., Akuma \& Callaghan, 2019; Athuman, 2017; Chabalengula \& Mumba, 2012; Leon, 2012; Ssempala, 2017). Inquiry instruction is a contemporary global approach for developing students' scientific literacy.

Empirical evidence shows widespread implementation of inquiry instruction in most industrialised and industrialising countries (e.g., Jiang \&
McComas, 2015; Pine et al., 2006; Smith et al., 2007; Tairab \& Al-Naqbi, 2018). Empirical evidence also shows successful and elaborate enactments of inquiry instruction in most industrialised and industrialising countries (e.g., Chang \& Wu, 2018; Crawford, 2000). In contrast, there is little evidence of inquiry science instruction in African schools. Instead, implementation of traditional science instruction persists in many African schools (e.g., Leon, 2012; Ramnarain \& Hlatswayo, 2018). The few reported cases of inquiry in African schools involve low levels of inquiry (e.g., Akuma \& Callaghan, 2018).

The situation may not be different in Ghanaian junior high schools (JHSs). While the current rationale for basic science education in Ghana is to engage all students in inquiry investigations into science phenomena in their

(C) 2020 by the authors; licensee Modestum. This article is an open access article distributed under the terms and conditions of the Creative Commons Attribution License (http://creativecommons.org/licenses/by/4.0/). 


\section{Contribution to the literature}

- While there are several successes and challenges in the implementation of inquiry-based science instruction in various contexts worldwide, including industrialised and industrialising countries, this study suggests that Ghana is one of the contexts where implementation of inquiry science instruction faces challenges.

- This study shows that interaction of school location and school type significantly influence the implementation of inquiry-based science instruction.

- Contrary to the general assumption that urban schools engage in better science instructional activities than rural schools, this study suggests that it is urban private but not all urban JHSs that engage in better science instructional activities than rural schools.

- While successful implementation of inquiry-based science instruction in many contexts globally involved students who are proficient or native-speakers of the instructional language, this study suggests that implementation of inquiry science instruction in most Ghanaian junior high schools, especially rural and public schools, may be problematic without the code-switching of English and the students' home language.

physical environment (Curriculum Research and Development Division [CRDD], 2007, 2012), there is little evidence of the extent of implementation of inquiry science instruction in Ghanaian JHSs. Besides, while many inquiry-based studies are conducted in the industrialised and industrialising countries, there is little evidence of such studies in the Ghanaian context.

\section{Purpose of the Study}

The purpose of our study was to investigate the extent of implementation of inquiry-based science teaching and learning in Ghanaian JHSs. The research questions used in this study are:

1. What is the extent of implementation of inquirybased science teaching and learning in Ghanaian JHSs?

2. What is the interaction of school location (urban versus rural) and school type (public versus private) on the implementation of inquiry-based science teaching and learning in Ghanaian JHSs?

\section{Conceptual Framework}

\section{Traditional science instruction}

Teachers occupy centre-stage in traditional science instruction. They transmit scientific knowledge to students who commit the received knowledge into memory by rote learning, without or with little questioning (e.g., Jegede, 1993; Grigg et al., 2013). Most traditional instruction occur through lectures, chalk and talk method, question and answer sessions, textbook reading, and giving of notes to students (e.g., Ampiah, 2008; Oppong-Nuako et al., 2015). Hands-on activities in traditional science instruction are confirmatory laboratory experiments (e.g., Grigg et al., 2013) and teacher demonstrations. Traditional science instruction is less effective in developing students' critical thinking, creativity, and problem-solving skills (e.g., Ampiah,
2006; Shumba, 1999), and stifles students from developing the meaning and appreciating the relevance of science.

\section{Inquiry-based science teaching and learning}

In inquiry science instruction students engage in and learn the activities and reasoning that actual scientists employ (e.g., Furtak et al., 2012) to "study the natural world and propose explanations based on evidence" (NRC, 1996, p. 23). This constructivist approach contextualises science instruction in interesting, meaningful, and relevant real-world phenomena (e.g., Crawford, 2000). Furtak et al. (2012) categorised inquiry teaching and learning into five domains. These are the procedural, epistemic, conceptual, social, and guidance activities that occur during science lessons.

In the procedural domain students ask scientificallyoriented questions that drive investigations; plan and design investigation procedures; and execute procedures to collect data (e.g., Crawford, 2000; Furtak et al., 2012). In the epistemic domain students examine and evaluate the quality of data from investigations; resolve inconsistencies in the data; analyse the data to identify patterns; and interpret the data by drawing inferences and conclusions, and making predictions and generalisations (e.g., Crawford, 2000). In the conceptual domain students draw on their prior knowledge and scientific facts and principles to understand and explain phenomena (Furtak et al., 2012). They search for information from books, internet, and articles to formulate hypotheses, and construct and check the validity of their explanations (e.g., Crawford, 2000). Students also use logical and critical thinking, consider alternative explanations (NRC, 1996), and learn concepts embedded in the processes of science.

In the social domain students work in groups; engage in discussions, presentations, modelling, collective decision-taking, and sharing ideas (e.g., Crawford, 2000; Furtak et al., 2012). In the guidance domain teachers 
assume multiple, changing, and demanding roles. They create "critical incidents" which allow investigation to proceed and provide avenues for students to learn the essential features of inquiry (Crawford, 2000, p. 927). Teachers employ extensive questioning to guide and stimulate students' thinking, actions, discussions, and collaborations (e.g., Crawford, 2000; Hansen \& Buczynski, 2013).

\section{Effectiveness of inquiry teaching and learning}

Generally, inquiry-based science instruction is effective in promoting learning outcomes of diverse students, in various disciplines, at various grades, in various contexts, and for both sexes. It is effective in improving students' science achievements (e.g., Furtak et al., 2012), conceptual understanding (e.g., Mamombe, et al., 2020; Simsek \& Kabapinar, 2010), content knowledge (e.g., Chang \& Mao, 1999;), motivation (e.g., Romero-Ariza et al., 2020), critical and higher-order thinking skills (e.g., Gillies, 2008), problem-solving skills (Gillies, 2008), attitudes toward science (e.g., Chang \& Mao, 1999), and science process skills (e.g., Simsek \& Kabapinar, 2010) among others. Inquiry science instruction is also effective in improving students' outcomes in earth science (Chang \& Mao, 1999), particulate nature of matter in the gaseous phase (Mamombe et al., 2020), Classification of non-living things (Gillies, 2008), physical science (Wolf \& Fraser, 2008), and matter (Simsek \& Kabapinar, 2010). It is effective in improving learning outcomes of elementary school (e.g., Simsek \& Kabapinar, 2010), middle school (e.g., Wolf \& Fraser, 2008), junior high school (Chang \& Mao, 1999), and vocational high school (Chang \& Wu, 2018) students.

\section{Science instruction for English language learners (ELLs)}

While developed countries like the USA have a growing population of ELLs, (e.g., Lee \& Buxton, 2013), most children in Africa are second language learners, ELLs inclusive. Besides, English and other second languages are the official instructional media at higher grades in most African countries (e.g., Clegg \& Afitska, 200). Clearly, providing science education for second language learners poses greater challenges for African countries than for developed countries.

The limited English proficiency of ELLs hinder their science achievements in classrooms where English only is used for instruction (e.g., August et al., 2010). One effective approach used in developed countries to promote ELLs' science learning and English acquisition simultaneously is the inquiry approach (e.g., Cuevas et al., 2005; Lee, 2005). However, empirical evidence shows that the inquiry approach is more effective for nativeEnglish students (Estrella et al., 2018), and is inadequate in promoting comparable achievements between nativeEnglish students and ELLs (August et al., 2010). Code- switching of English and the home language during inquiry instruction is another effective approach used to promote ELLs' science learning outcomes (e.g., Jantjies \& Joy, 2015; Lee, 2005; Sliva \& Kucer, 2016). Codeswitching allows teachers to use home language equivalents of English vocabularies and key science concepts for comparisons, explanations (Macaro \& Lee, 2013), analogies, and facilitation of ELLs' explorations (Clegg \& Afitska, 2011). Code-switching also allows ELLs to apply their home language skills in constructing meaning to link science content to their prior experiences, and link abstract concepts to concrete objects, phenomena, and events (Lee, 2005).

\section{Influence of school location and school type on inquiry science instruction}

There is inconclusive evidence about the influence of school location (rural versus urban) and school type (public versus private) on the implementation of inquiry science instruction. While empirical evidence shows good and successful implementation of inquiry instruction in rural (e.g., Crawford, 2000), urban (e.g., Athuman, 2017), public (e.g., Crawford, 2000), and private schools (e.g., Smith et al., 2007); evidence also shows poor and challenging implementation in rural (e.g., Ramnarain \& Hlatswayo, 2018), public (e.g., Ramnarain \& Hlatswayo, 2018), urban (e.g., Akuma \& Callaghan, 2018), and private (e.g., Leon, 2012) schools. Again, while there is apparent comparable implementation of inquiry-based instruction in rural (e.g., Crawford, 2000) and urban (e.g., Smith et al., 2007) classrooms in developed countries like the USA, there seems to be mixed implementation of inquiry instruction in rural (e.g., Hlatswayo \& Ramnarain, 2018) and urban (e.g., Athuman, 2017) classrooms in Africa.

Nonetheless, most researchers agree that educational development and students' achievements in African rural areas is behind educational development and students' achievements in the urban centres (Addy, 2013; Somuah \& Mensah, 2013).

\section{METHODS}

\section{Research Design}

We used concurrent triangulation mixed methods design to collect quantitative and qualitative data (e.g., Creswell, 2009). Surveys involving questionnaires and structured observations were used to collect the quantitative data. Multiple case studies involving semistructured interviews were used to collect the qualitative data (e.g., Cohen et al., 2007). We analysed the two data types separately and integrated the results and discussions. This design enabled us to use the qualitative results to corroborate and interpret the quantitative results. Key limitations of this design are the difficulties 
and efforts required to compare and resolve inconsistencies that may arise from the two data types.

\section{Sample}

We purposively sampled two rural districts, one urban and one urban-rural municipalities from the Central Region of Ghana. This was done because of differences in socio-economic conditions of the different school locations. Rural areas are characterised by schools with low enrolment, high dropout rates, poor infrastructure and science equipment, inability to attract and retain qualified science teachers, poor performance in examinations, and poor management and supervision of school activities. Rural areas are also characterised by parents with low formal education, low income levels, and little interest in their children's education. Contrary, schools in urban areas attract and retain qualified science teachers, have good infrastructure and science equipment, perform well in examinations, and undertake good management and supervision of learning activities. Urban areas are also characterised by parents with high levels of formal education, high income levels, and deep interest in their children's education (Addy, 2013; Somuah \& Mensah, 2013).

We also selected 16 public and private JHSs from the districts and municipalities using stratified random procedure. Public and private JHSs were sampled because private JHS students tend to outperform public JHS students in examinations, have their own textbooks, are more fluent in English, and participate actively in class discourse (Ampiah 2008). Besides, parents of private JHS students value education of their children, have the ability to finance the children's education, and provide adequate resources for the children's education (Sassenrath et al., 1984).

Additionally, we purposively sampled one director and three deputy directors of education, three science coordinators, and four circuit supervisors. Twelve head teachers from the JHSs were also purposively selected. In all, 23 educational administrators (director and deputy directors of education, science coordinators, circuit supervisors, and head teachers) participated in the study. We sampled the administrators because they are in charge of the supervision, management, and administration of educational activities, including science teaching and learning. Some educational administrators were not available for interviewing. Sixteen administrators were males, seven were females. Most of their ages ranged 46-58 years. Administrators from the Ghana Education Service (GES) offices and government JHSs had professional teacher training with BED, BSC, MED, and MPhil qualifications. Administrators from the private JHSs had no professional training. Most of the administrators had 2628 years working experience in education.
Again, 16 integrated science teachers were purposively sampled from the JHSs. Additional two teachers volunteered to participate in the study. We sampled the integrated science teachers because they play key roles in the implementation of inquiry-based activities in classrooms. Ten teachers were from public and eight from private JHSs. Seventeen were males, one was female. All teachers from the public JHSs had professional training with DBE and BED qualifications. All teachers from the private JHSs had no professional training and were holders of WASSCE, Diploma, and HND certificates. Ages of the teachers ranged 21-40 years. Most of them had 2-7 years teaching experience. Two had 13 years, one had 15 years, and another one had 1 year teaching experience.

We also selected 503 JHS 2 students purposively. Students were involved because inquiry-based activities are student-centred. This large sample is comparable to those in other studies (e.g., Wolf \& Fraser, 2008). More than half of the students were females $261(51.89 \%$ ) with $242(48.11 \%)$ being males. Most of them were from urban centres 301(59.84\%) with 202(40.16\%) from rural areas.

\section{Instruments}

We used a students' questionnaire, two lesson observation protocols, and a semi-structured interview schedule for data collection.

\section{Students' questionnaire}

We designed this questionnaire for students to rate how often inquiry activities were implemented in science lessons. The design and development of this questionnaire drew on instruments used in other contexts (e.g., Campbell et al., 2010), and was based on Furtak et al.'s (2012) model of inquiry. It was designed on a 5 -point Likert scale $(1=$ never, $2=\mathrm{a}$ few lessons, $3=$ half the lessons, $4=$ most of the lessons, $5=$ all the lessons). Items were constructed to cover the five domains of inquiry. We used extensive literature and expert judgements from two science education professors at the University of Cape Coast, Ghana to establish content validity of the items. We piloted the questionnaire using JHS 2 students from one municipality in the Central Region of Ghana.

Confirmatory Principal Component Analysis with varimax rotation showed that the questionnaire had sufficient construct validity. The five extracted components accounted for $59.95 \%$ of total variance in the items. This is large and comparable to variances in other studies (e.g., Van Aalderen-Smeets \& Walma van der Molen, 2013).

Reliabilities of the components (procedural, $\alpha=.74$; epistemic, $\alpha=.76$; conceptual, $\alpha=.83$; social, $\alpha=.78$; guidance, $\alpha=.74)$ and entire instrument $(\alpha=.73)$ were acceptable for research (e.g., Suhr, 2006). 


\section{Lesson observation protocols}

We designed and developed two protocols to observe and rate inquiry activities during integrated science lessons. The design and development of the protocols drew on the Reformed Teaching Observation Protocol (RTOP) (e.g., Cianciolo et al., 2006), and was based on Furtak et al.'s (2012) model of inquiry. Items were constructed to cover the five domains. Content validity of the protocols were established using extensive literature and expert judgements from the two science education professors.

Observation protocol 1 was designed on a momentary event sampling format. Observation protocol 2 was designed on a 5-point Likert scale $(1=$ never, $2=$ rarely, $3=$ sometimes, $4=$ often, to $5=$ very often). Protocol 1 was for recording specific activities observed at 1-minute intervals. Results from protocol 1 were used to complete protocol 2. The protocols were piloted through observations of 10 science lessons in JHS 2 classrooms. Reliability of observation protocol 2 ( $a=$ .74) was acceptable for research.

\section{Interview schedule}

Apart from items used to elicit participants' demographics and served as ice-breaking questions, the schedule had one main open-ended item. The item required respondents to express the extent of inquiry teaching and learning in JHSs. It also allowed respondents to fully express their experiences and views. The item allowed the interviewer to probe, prompt, and follow-up participants' responses (e.g., Jacob \& Furgerson, 2012). The schedule was piloted through individual face-to-face interviews with six science teachers, three head teachers, one circuit supervisor, one science coordinator, and a deputy director of education.

\section{Data Collection Procedure}

We wrote letters to directors of education and head teachers to seek permissions for access into the schools and offices for the study. We collected lists of public and private JHSs from the directors and lists of JHS 2 students from the head teachers. We used the lists to sample the schools and students. We informed all the participants about the purpose of our study and sought their involvement and cooperation. Participants' anonymity, confidentiality, privacy, freedom and right of participation and withdrawal were observed in the study. We administered questionnaires to the JHS 2 students in their classrooms. We also observed and rated 31 integrated science lessons in JHS 2 classrooms in 16 schools. Most of the lessons lasted 70 minutes. Individual face-to-face semi-structured interviews with science teachers and educational administrators were conducted. Signed consents were obtained from educational and school authorities and from interviewees. Sufficient rapport was established with the interviewees. All the interviews were audio recorded. Most of the interviews lasted about 30 minutes.

\section{Data Analysis}

The quantitative data was screened for outliers and missing values prior to the main analysis. Negative worded items were recoded. Prior analysis for parametric tests showed that assumptions of normality, linearity, multicollinearity, and equality of variance and covariance had not been violated. The qualitative data analysis began with transcription of all the audio recorded interviews, followed by auditing and editing of the transcripts. To determine the extent of implementation of inquiry teaching and learning in the JHSs, we calculated average item means and standard deviations, frequencies, and percentages of the quantitative data from students' and lesson observation ratings; and conducted thematic analysis of qualitative data from interviews with the participants.

To determine differences in inquiry teaching and learning between public and private JHSs in urban and rural areas, we conducted two-way MANOVA using data from the students' ratings. In this analysis school location (urban versus private) and school type (public versus private) were the independent variables and components of inquiry (procedural, epistemic, conceptual, social, and guidance) were the dependent variables. We also conducted thematic analysis of qualitative data from the interviews.

\section{RESULTS}

\section{Research Question 1}

We triangulated results from the students' and lesson observation ratings, and interview responses to answer research question 1 .

\section{Students' ratings}

Overall average item mean $(M=1.99, S D=.48)$ from the students' ratings shows that inquiry-based science teaching and learning was implemented in a few lessons per term in the JHSs. Specifically, the procedural aspect of inquiry was apparently not implemented $(M=1.46$, $S D=.60$ ). Most of the students' ratings show that they never planned and designed their own experiments 401 (79.7\%), performed experiments 357 (71.0\%), and collected and recorded data 333 (66.2.5) (Table 1).

The conceptual aspect of inquiry was implemented in a few lessons per term $(M=1.91, S D=.99)$. More than half of the ratings indicate that the students never formulated hypotheses 279 (55.5\%) and explained science phenomena based on their prior knowledge 262 $(52.1 \%)$. Again, a significant number of the ratings show that in a few lessons per term that formulation of hypotheses $124(24.7 \%)$ and explanation of phenomena 
Table 1. Average item means, average item standard deviations, frequencies, and percentages of students' ratings of termly implementation of aspects of inquiry teaching and learning in JHSs

\begin{tabular}{|c|c|c|c|c|c|c|c|}
\hline \multirow{3}{*}{$\begin{array}{l}\text { Aspect/domain of inquiry teaching and } \\
\text { learning }\end{array}$} & \multicolumn{7}{|c|}{ Responses per term } \\
\hline & Never & $\begin{array}{c}\text { In a few } \\
\text { lessons }\end{array}$ & $\begin{array}{l}\text { In half the } \\
\text { lessons }\end{array}$ & $\begin{array}{l}\text { In most } \\
\text { lessons }\end{array}$ & $\begin{array}{c}\text { In all } \\
\text { lessons }\end{array}$ & $\begin{array}{l}\text { Average } \\
\text { item }\end{array}$ & $\begin{array}{l}\text { Average item } \\
\text { standard }\end{array}$ \\
\hline & $\mathrm{n}(\%)$ & $\mathrm{n}(\%)$ & $\mathrm{n}(\%)$ & $\mathrm{n}(\%)$ & $\mathrm{n}(\%)$ & mean & deviation \\
\hline Social & & & & & & 2.48 & 1.03 \\
\hline Student engages in class discussions. & $133(26.4)$ & 94(18.7) & $61(12.1)$ & $79(15.7)$ & $136(27.0)$ & & \\
\hline $\begin{array}{l}\text { Student communicates and share scientific } \\
\text { ideas with class mates. }\end{array}$ & $180(35.8)$ & $114(22.7)$ & $85(16.9)$ & $66(13.1)$ & $58(11.5)$ & & \\
\hline $\begin{array}{l}\text { Student reasons and take collective decisions } \\
\text { with mates. }\end{array}$ & 205(40.8) & $121(24.1)$ & $71(14.1)$ & $64(12.7)$ & $42(8.3)$ & & \\
\hline $\begin{array}{l}\text { Student collaborates with classmates to } \\
\text { understand science knowledge and processes. }\end{array}$ & $193(38.4)$ & $129(25.6)$ & $81(16.1)$ & $50(9.9)$ & $50(9.9)$ & & \\
\hline Student Work in groups. & $163(32.4)$ & $131(26.0)$ & $81(16.1)$ & $54(10.7)$ & $74(14.7)$ & & \\
\hline Guidance & & & & & & 1.99 & 0.87 \\
\hline Teacher leads discussions. & $50(9.9)$ & $55(10.9)$ & $50(9.9)$ & $134(26.6)$ & $214(42.5)$ & & \\
\hline Teacher defines and states concepts. & $35(7.0)$ & $39(7.8)$ & $36(7.2)$ & 77(15.3) & $316(62.8)$ & & \\
\hline Teacher tells expected answers. & $39(7.8)$ & $50(9.9)$ & $66(13.1)$ & $128(25.4)$ & $220(43.7)$ & & \\
\hline Student work individually. & $30(6.0)$ & $55(10.9)$ & $38(7.6)$ & $111(22.1)$ & $269(53.5)$ & & \\
\hline Teacher does most talking in class. & 15(3.0) & $34(6.8)$ & $48(9.5)$ & $178(35.4)$ & $228(45.3)$ & & \\
\hline Epistemic & & & & & & 1.97 & 0.92 \\
\hline Student explains phenomena based on data. & 251(49.9) & $139(27.6)$ & $51(10.1)$ & $31(6.2)$ & $31(6.2)$ & & \\
\hline $\begin{array}{l}\text { Student learns science concepts through } \\
\text { experimentation. }\end{array}$ & $135(26.8)$ & $228(45.3)$ & $56(11.1)$ & $42(8.3)$ & $42(8.3)$ & & \\
\hline $\begin{array}{l}\text { Student change old understanding based on } \\
\text { data. }\end{array}$ & $262(52.1)$ & $160(31.8)$ & $40(8.0)$ & $32(6.4)$ & $9(1.8)$ & & \\
\hline Conceptual & & & & & & 1.91 & 0.99 \\
\hline $\begin{array}{l}\text { Student formulates hypotheses for science } \\
\text { phenomena. }\end{array}$ & $279(55.5)$ & $124(24.7)$ & $58(11.5)$ & $24(4.8)$ & 18(3.6) & & \\
\hline $\begin{array}{l}\text { Student explains phenomena based on prior } \\
\text { knowledge. }\end{array}$ & $262(52.1)$ & $136(27.0)$ & $48(9.5)$ & $26(5.2)$ & $31(6.2)$ & & \\
\hline $\begin{array}{l}\text { Student learns concepts in the processes of } \\
\text { science. }\end{array}$ & $193(38.4)$ & $184(36.6)$ & $45(8.9)$ & $47(9.3)$ & $34(6.8)$ & & \\
\hline Procedural & & & & & & 1.46 & 0.60 \\
\hline Student plans and designs experiments. & 401(79.7) & 79(15.7) & $15(3.0)$ & $5(1.0)$ & $3(0.6)$ & & \\
\hline Student Performs experiments. & $357(71.0)$ & $119(23.7)$ & 18(3.6) & $2(0.4)$ & $7(1.4)$ & & \\
\hline $\begin{array}{l}\text { Student handles and uses science equipment } \\
\text { and materials. }\end{array}$ & $284(56.5)$ & $157(31.2)$ & $29(5.8)$ & $19(3.8)$ & $14(2.8)$ & & \\
\hline Student collect and record data. & $333(66.2)$ & $116(23.1)$ & $23(4.6)$ & $24(4.8)$ & $7(1.4)$ & & \\
\hline Overall inquiry & & & & & & 1.99 & 0.48 \\
\hline
\end{tabular}

$\mathrm{N}=503$

Note: Average item means could range from 1(never) to 5(all lessons), with high means indicating inquiry-based and low means indicating traditional-oriented activities.

based on prior knowledge 136 (27.0\%) occurred. The epistemic aspect of inquiry was also implemented in a few lessons per term $(M=1.97, S D=.92)$. More than half of the students' ratings indicate that they never changed their understandings of science concepts based on evidence $262(52.1 \%)$. Half of the ratings also shows that the students never explained science phenomena based on data $251(49.9 \%)$, while a sizeable number of ratings show that in a few lessons per term that learning science through experimentation $228(45.3 \%)$ and explaining phenomena based on data 139 (27.6\%) occurred.

Similarly, the guidance aspect of inquiry was implemented in a few lessons per term $(M=1.99, S D=$ .87). Instead, the guidance aspect of traditional science instruction was predominantly implemented in the JHSs. Most of the students' ratings indicate that they sat individually behind their desks 380 (75.6\%) with teachers doing most of the talking 406 (80.7\%) through definitions and statements of science concepts and principles $393(78.1 \%)$ in all or most of the lessons. While the social aspect of inquiry $(M=2.48, S D=1.03)$ was considerably implemented in the JHSs, the social aspect of traditional science instruction was largely implemented. A sizeable proportion of the students' ratings indicates that they never engaged in class discussions $133(26.4 \%)$, group work 163 (32.4\%), and communication and sharing of ideas with their mates $180(35.8 \%)$. Another sizeable proportion indicates that in a few lessons per term that the students engaged in class discussions 94 (18.7\%), group work 131 (26.0\%), and communication and sharing of ideas with their mates $114(22.7 \%)$. 
Table 2. Average item means, average item standard deviations, frequencies, and percentages of classroom observation ratings of aspects of inquiry teaching and learning in JHSs

\begin{tabular}{|c|c|c|c|c|c|c|c|}
\hline \multirow{3}{*}{$\begin{array}{l}\text { Aspect/domain of inquiry teaching and } \\
\text { learning }\end{array}$} & \multicolumn{7}{|c|}{ Responses per term } \\
\hline & Never & $\begin{array}{l}\text { In a few } \\
\text { lessons }\end{array}$ & $\begin{array}{l}\text { In half the } \\
\text { lessons }\end{array}$ & $\begin{array}{l}\text { In most } \\
\text { lessons }\end{array}$ & $\begin{array}{c}\text { In all } \\
\text { lessons }\end{array}$ & $\begin{array}{l}\text { Average } \\
\text { item }\end{array}$ & $\begin{array}{l}\text { Average item } \\
\text { standard }\end{array}$ \\
\hline & $\mathrm{n}(\%)$ & $\mathrm{n}(\%)$ & $\mathrm{n}(\%)$ & $\mathrm{n}(\%)$ & $\mathrm{n}(\%)$ & mean & deviation \\
\hline Guidance & & & & & & 2.46 & 0.50 \\
\hline Teachers elicit students' prior knowledge. & $0(0.0)$ & $2(6.5)$ & $6(19.4)$ & $22(71.0)$ & $1(3.2)$ & & \\
\hline $\begin{array}{l}\text { Teachers observe and listen to students' } \\
\text { interactions. }\end{array}$ & $30(96.8)$ & $1(3.2)$ & $0(0.0)$ & $0(0.0)$ & $0(0.0)$ & & \\
\hline $\begin{array}{l}\text { Teachers deliver content through lectures and } \\
\text { discussions. }\end{array}$ & $0(0.0)$ & $1(3.2)$ & $6(19.4)$ & $14(45.2)$ & $10(32.3)$ & & \\
\hline $\begin{array}{l}\text { Teachers write facts and concepts on } \\
\text { chalkboard. }\end{array}$ & $0(0.0)$ & $2(6.5)$ & $11(35.5)$ & $15(48.4)$ & $3(9.7)$ & & \\
\hline Teacher reads scientific facts from textbooks. & 11(35.5) & $4(12.9)$ & $15(48.4)$ & $0(0.0)$ & $1(3.2)$ & & \\
\hline $\begin{array}{l}\text { Teachers define and explain science concepts } \\
\text { and principles. }\end{array}$ & $1(3.2)$ & $2(6.5)$ & $6(19.4)$ & $14(45.2)$ & $8(25.8)$ & & \\
\hline Students answer questions posed by teachers. & $1(3.2)$ & $4(12.9)$ & $11(35.5)$ & $12(38.7)$ & $3(9.7)$ & & \\
\hline Procedural & & & & & & 1.23 & 0.16 \\
\hline Students ask scientifically oriented questions. & $10(32.3)$ & $18(58.1)$ & $3(9.7)$ & $0(0.0)$ & $0(0.0)$ & & \\
\hline Students plan and design experiments. & $31(100.0)$ & $0(0.0)$ & $0(0.0)$ & $0(0.0)$ & $0(0.0)$ & & \\
\hline $\begin{array}{l}\text { Students manipulate materials and } \\
\text { equipment. }\end{array}$ & 28(90.3) & $3(9.7)$ & $0(0.0)$ & $0(0.0)$ & $0(0.0)$ & & \\
\hline Students collect and record data. & $30(96.8)$ & $1(3.2)$ & $0(0.0)$ & $0(0.0)$ & $0(0.0)$ & & \\
\hline Social & & & & & & 1.05 & 0.19 \\
\hline $\begin{array}{l}\text { Students communicate to peers and teachers } \\
\text { and make their ideas public. }\end{array}$ & $29(93.5)$ & $2(6.5)$ & $0(0.0)$ & $0(0.0)$ & $0(0.0)$ & & \\
\hline $\begin{array}{l}\text { Students collaborate to construct scientific } \\
\text { knowledge. }\end{array}$ & $29(93.5)$ & $2(6.5)$ & $0(0.0)$ & $0(0.0)$ & $0(0.0)$ & & \\
\hline $\begin{array}{l}\text { Students work in groups to reach collective } \\
\text { scientific decisions. }\end{array}$ & $29(93.5)$ & $2(6.5)$ & $0(0.0)$ & $0(0.0)$ & $0(0.0)$ & & \\
\hline Epistemic & & & & & & 1.01 & 0.04 \\
\hline Students interpret phenomena based on data. & $31(100.0)$ & $0(0.0)$ & $0(0.0)$ & $0(0.0)$ & $0(0.0)$ & & \\
\hline $\begin{array}{l}\text { Students examine and evaluate quality of } \\
\text { data. }\end{array}$ & $30(96.8)$ & $1(3.2)$ & $0(0.0)$ & $0(0.0)$ & $0(0.0)$ & & \\
\hline $\begin{array}{l}\text { Students change understanding based on } \\
\text { data. }\end{array}$ & $31(100.0)$ & $0(0.0)$ & $0(0.0)$ & $0(0.0)$ & $0(0.0)$ & & \\
\hline $\begin{array}{l}\text { Students learn that their processes are similar } \\
\text { to work of actual scientists. }\end{array}$ & $31(100.0)$ & $0(0.0)$ & $0(0.0)$ & $0(0.0)$ & $0(0.0)$ & & \\
\hline Conceptual & & & & & & 1.00 & 0.00 \\
\hline $\begin{array}{l}\text { Students formulate hypotheses based on } \\
\text { prior knowledge. }\end{array}$ & $31(100.0)$ & $0(0.0)$ & $0(0.0)$ & $0(0.0)$ & $0(0.0)$ & & \\
\hline $\begin{array}{l}\text { Students check explanations against } \\
\text { established scientific knowledge. }\end{array}$ & $31(100.0)$ & $0(0.0)$ & $0(0.0)$ & $0(0.0)$ & $0(0.0)$ & & \\
\hline $\begin{array}{l}\text { Students consider alternative explanations for } \\
\text { phenomena. }\end{array}$ & $31(100.0)$ & $0(0.0)$ & $0(0.0)$ & $0(0.0)$ & $0(0.0)$ & & \\
\hline $\begin{array}{l}\text { Students learn content embedded in } \\
\text { processes of science. }\end{array}$ & $31(100.0)$ & $0(0.0)$ & $0(0.0)$ & $0(0.0)$ & $0(0.0)$ & & \\
\hline Overall inquiry & & & & & & 1.47 & 0.17 \\
\hline
\end{tabular}

\section{$\mathrm{N}=31$}

Note: Average item means could range from 1(never) to 5(very often), with high means indicating inquiry-based and low means indicating traditional-oriented activities.

\section{Lesson observation ratings}

Overall average item mean $(M=1.47, S D=.17)$ from the observation ratings also shows apparent no implementation of inquiry-based science instruction in the JHSs. Specifically, the conceptual aspect of inquiry was apparently not implemented $(M=1.00, S D=.00)$. Ratings from all lesson observations show that the students never formulated hypotheses 31 (100.0\%), explained phenomena based on prior their knowledge $31(100.0 \%)$, considered alternative explanations of phenomena $31(100.0 \%)$, checked their explanations against existing scientific knowledge 31 (100.0\%), and learned content embedded in the processes of science 31 $(100.0 \%)$ (Table 2).

Similarly, the epistemic aspect of inquiry was apparently not implemented $(M=1.01, S D=.04)$. Ratings from all lesson observations show that the 


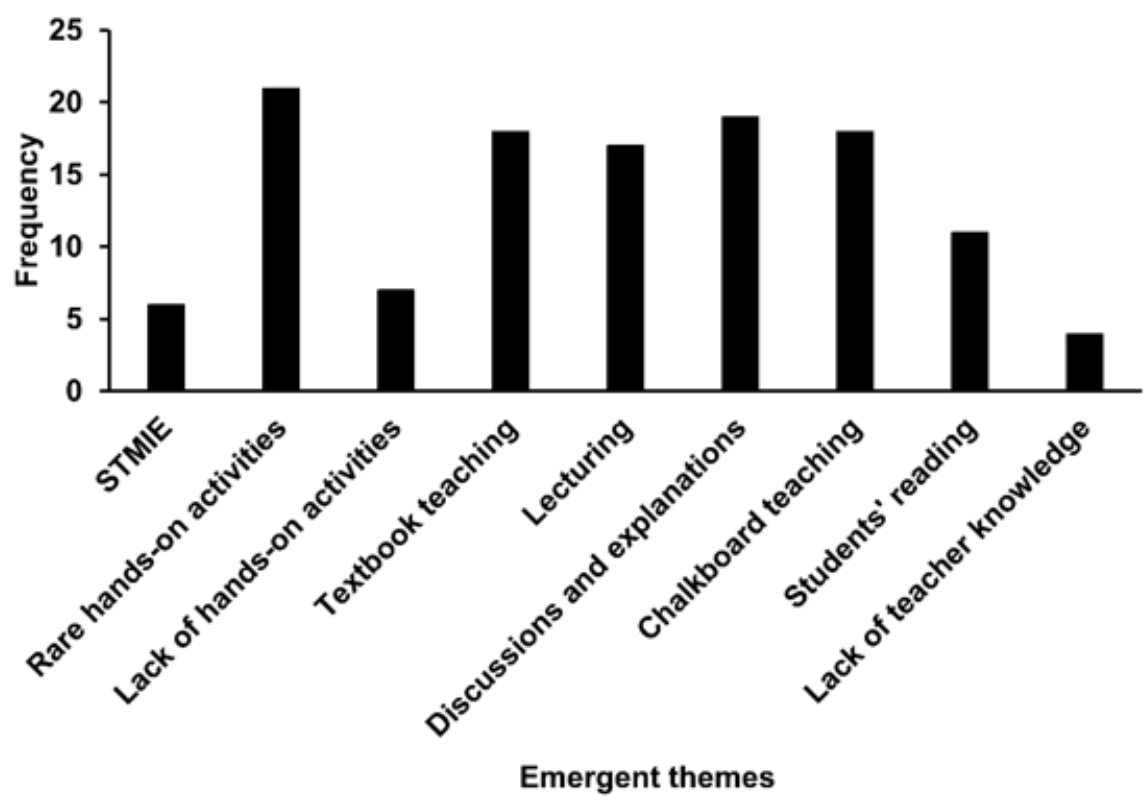

Figure 1. Emergent themes about science teaching and learning from interview responses of teachers and educational administrators

students never changed their understandings of science concepts $31(100.0 \%)$ and explained phenomena 31 $(100.0 \%)$ based on data, and never learned the similarity between their work and that of actual scientists 31 $(100.0 \%)$. Again, the social aspect of inquiry was apparently not implemented $(M=1.05, S D=.19)$. Ratings from most lessons observed show that the students never worked in groups to reach collective scientific decisions 29 (93.5\%), collaborated with their peers to construct scientific knowledge 29 (93.5\%), and communicated with peers to make their ideas public 29 $(93.5 \%)$. The procedural aspect of inquiry was also apparently not implemented $(M=1.23, S D=.16)$. Ratings from most lesson observations show that the students never planned and designed their own experiments $31(100.0 \%)$, collected and recorded data 30 $(96.8 \%)$, and manipulated science equipment and materials $28(90.3 \%)$.

While some guidance aspect of inquiry was implemented $(M=2.46, S D=.50)$, the guidance aspect of traditional science instruction was largely implemented. Ratings from most lesson observations show that JHS teachers never observed and listened to students' interactions 30 (96.8\%). Instead, they often and very often delivered science concepts and principles through lectures and discussions 24 (77.5\%), definitions and explanations $22(71.0 \%)$, and wrote notes on board for students to copy $18(58.1 \%)$.

\section{Interview responses}

Emergent themes from interview responses of the teachers and educational administrators also reveal a general rare implementation of inquiry science instruction in the JHSs. Only a few interviewees (6 out of 41) said that inquiry-based Science, Technology,
Mathematics, Innovation, and Education (STMIE) clinics were implemented in JHSs (Figure 1).

STMIE is a programme for JHS students to use local and other materials to make products and models for exhibition at science clinics or fairs. However, interviewees responses indicate that STMIE fairs were rarely implemented. One science coordinator said: "These days the STMIE has not been functional. We should have had one at the end of last term, but it didn't come one." A head teacher also said: "There have been two science clinics for children since I came to this school about four years ago."

While more than half of the interviewees (21 out of 41) said that hands-on activities rarely occurred in JHSs, a number of them (7 out of 41) said that hands-on activities never occurred. A deputy director of education said: "Teachers don't organise experiment for students. Everything [teaching] is done by theory." A science teacher also said: "I don't allow the students to plan and perform their own experiments ... because we don't have many of the basic instruments." In occasions when students were engaged in hands-on activities, they were given the same sets of equipment and materials, and followed the same stepby-step procedures to arrive at the same answers. A science teacher said: "Allowing children to perform experiments with guidance is good. By guidance I mean students should be given instructions and steps necessary to perform the experiments."

Interviewees responses also reveal that the conceptual aspect of inquiry was rarely implemented in the JHSs. Instead, it was the conceptual aspect of traditional instruction that was predominantly implemented. This involved students reading textbooks for contributions to traditional question and answer and discussion sessions. One science teacher said: "Prior to 
Table 3. Two-way ANOVA results ( $\mathrm{F}$ and $\mathrm{eta}^{2}$ ) for school location and school type for students' ratings of termly implementation of aspects of inquiry teaching and learning in JHSs

\begin{tabular}{lcccccc}
\hline \multirow{2}{*}{$\begin{array}{l}\text { Aspect of inquiry teaching and } \\
\text { learning }\end{array}$} & \multicolumn{3}{c}{ Two-way ANOVA results } \\
\cline { 2 - 6 } & \multicolumn{2}{c}{ School location } & \multicolumn{2}{c}{ School type } & \multicolumn{2}{c}{ School location $\times$ School type } \\
\cline { 2 - 6 } & $F$ & $E^{2}$ & $F$ & $E^{2}$ & $E^{2}$ & \\
\hline Social & 1.020 & 0.002 & $18.385^{*}$ & 0.036 & $44.724^{*}$ & 0.082 \\
Conceptual & $10.827^{*}$ & 0.021 & 0.643 & 0.001 & $17.219^{*}$ & 0.033 \\
Guidance & $3.859^{* *}$ & 0.008 & 0.000 & 0.000 & 2.039 & 0.004 \\
Procedural & 0.179 & 0.000 & $6.523^{* *}$ & 0.013 & $4.824^{* *}$ & 0.010 \\
Epistemic & 0.824 & 0.002 & 2.814 & 0.006 & 0.696 & 0.001 \\
\hline
\end{tabular}

${ }^{*} p<.01,{ }^{* *} p<.05, \mathrm{~N}=503$

the next lesson $I$ tell the students to do their own readings about the next topic, so that they will have some knowledge about it."

Interviewees responses also show that the guidance aspect of inquiry was not implemented in the JHSs. Instead, it was the guidance aspect of traditional instruction that was largely implemented. Many interviewees said that science instruction in JHSs involved textbook teaching (18 out of 41), lecturing (17 out of 41), discussions and explanations (19 out of 41), and chalkboard teaching (18 out of 41). A circuit supervisor said: "Some teachers refer to what is in the textbooks and write it on the blackboard." A deputy director of education also said: "What I saw was that teachers were just reading, giving notes, and explaining science concepts to students."

However, the interviewees responses show that some implementation of the social aspect of inquiry occurred in JHSs. A science teacher said: "I put the students into groups. I then give them guidelines to perform experiments, after which we come together as a class to discuss the results."

\section{Research Question 2}

We triangulated results from the students' and lesson observations ratings, and interviews responses to answer research question 2 .

\section{Students' ratings}

Results from the two-way MANOVA show statistically significant main effects of school location (urban versus private) and school type (public versus private), and an interaction effect of school location and school type on the implementation of inquiry-based science instruction in JHSs. Subsequent univariate ANOVAs at a Bonferroni adjusted alpha level of .01 show statistically significant interaction effects on the implementation of social $F(1,499)=44.724, p<.01$, partial $\mathrm{n}^{2}=.082$ and conceptual $F(1,499)=17.219, p<.01$, partial $\mathrm{n}^{2}=.033$ aspects of inquiry. The procedural aspect $F(1$, $499)=4.824, p<.029$, partial $\eta^{2}=.010$ is significant at the .05 significant level. The procedural (2.9\%) and conceptual $(3.3 \%)$ aspects yielded small effect sizes, but the social aspect yielded moderate effect size $(8.2 \%)$ (Table 3).
Figure 2a shows that urban private JHS students ( $M$ $=3.05, S D=.97$ ) engaged in social aspect of inquiry more than rural private JHS students $(M=2.53, S D=1.15)$, but rural public JHS students $(M=2.75, \mathrm{SD}=.95)$ engaged in social aspect of inquiry more than urban public JHS students $(M=2.04, \mathrm{SD}=.86)$. This indicates that urban private JHS students worked in groups, had class discussions and collaborations, and shared ideas in half of the science lessons per term, but rural private JHS students worked in groups, had class discussions and collaborations, and shared ideas in a few lessons per term. It also indicates that rural public JHS students worked in groups, had class discussions and collaborations, and shared ideas in nearly half of the science lessons per term, but urban public JHS students worked in groups, had class discussions and collaborations, and shared ideas in a few lessons per term.

Again, urban public JHS students $(M=1.59, S D=.81)$ engaged in conceptual aspect of inquiry lesser than rural public JHS students $(M=2.28, S D=1.12)$, but urban private $(M=2.05, S D=.93)$ and rural private $(M=1.97$, $S D=1.03) \mathrm{JHS}$ students engaged in conceptual aspect of inquiry less (Figure $2 b$ ). This indicates that urban public JHS students formulated hypotheses, explained phenomena based on their prior knowledge, and learned content embedded in the processes of science in fewer lessons per term than rural public JHS students.

Likewise, urban public JHS students $(M=1.36, S D=$ .62) engaged in procedural aspect of inquiry lesser than urban private JHS students $(M=1.63, S D=.49)$, but rural public $(M=1.46, S D=.53)$ and rural private $(M=1.48$, $S D=.76) \mathrm{JHS}$ students engaged in procedural aspect of inquiry less (Figure 2c). This indicates that urban public JHS students planned and designed experiments, handled and manipulated equipment and materials, performed experiments, and collected and recorded data in fewer lessons per term than urban private JHS students. 
Social aspect of inquiry

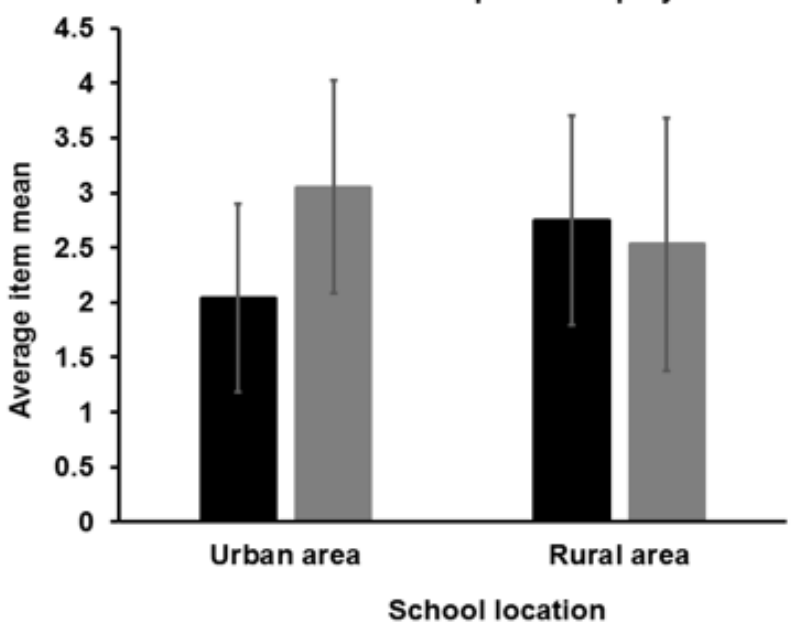

- Public JHSs

Private JHSs

(a)

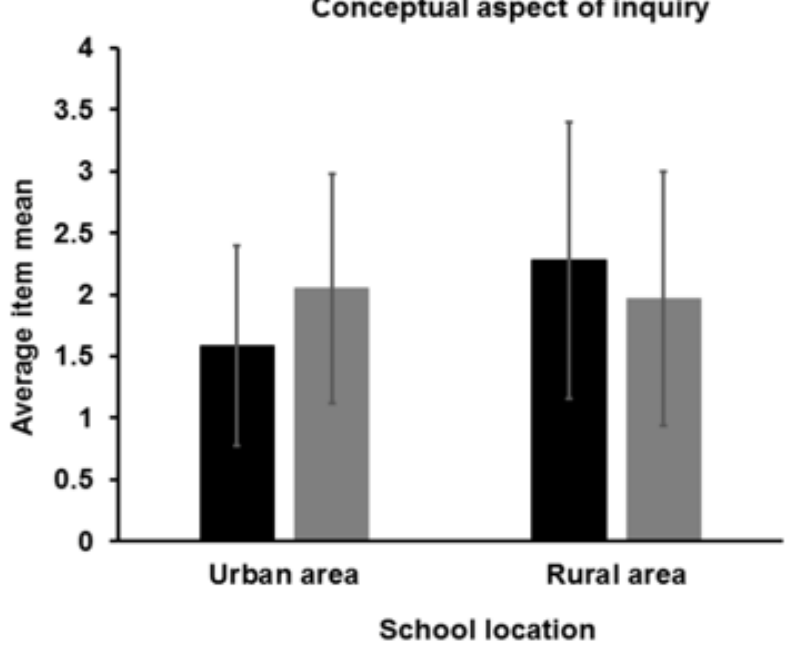

(b)

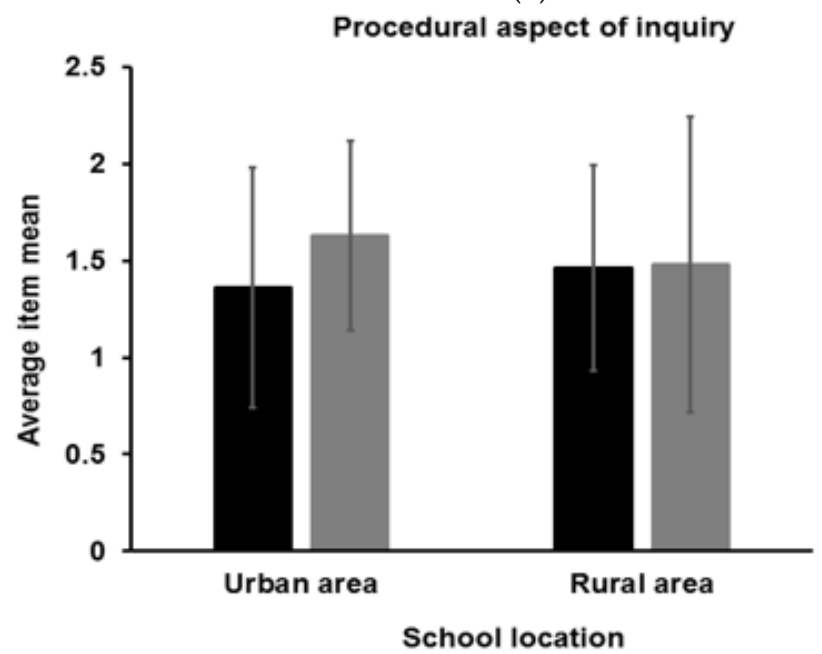

Public JHSs

- Private JHSs

(c)

Figure 2. a) School location by school type interaction on the implementation of social aspect of inquiry teaching and learning, b) School location by school type interaction on the implementation of conceptual aspect of inquiry teaching and learning, c) School location by school type interaction on the implementation of procedural aspect of inquiry teaching and learning 


\section{Lesson observation ratings}

Ratings from the lesson observations also show that urban public JHS students engaged in procedural aspect of inquiry lesser than urban private JHS students. In an observed lesson in one urban private JHS, the teacher prescribed step-by-step hands-on procedures for students to prepare dilute, concentrated, saturated, and supersaturated solutions of sugar, salt, hair and food dyes. Not a single hands-on activity was observed in all the lessons in urban public JHSs.

\section{Interview responses}

Results from the interviewees responses also show that urban private JHS students engaged in social aspect of inquiry more than rural private JHS students. Urban private JHS students often went on excursions and field trips, where they asked questions about science phenomena, engaged in discussions, shared scientific ideas, and collaborated to construct their own understandings. An urban private JHS head teacher said: "Every term the children go on excursions and field trips. Last term they went to Apostle Kojo Safo's [local] car manufacturing site. They asked a lot of questions." Interview responses also reveal that urban private JHS students were regularly tasked to read on science topics ahead of the next lessons. Therefore, the students got well prepared, took active part in class discussions, and shared ideas with their mates in class. An urban private JHS science teacher said: "I recently went to class and told the students to read about genetically modified food from several sources, and bring their findings to school for discussion."

In contrast, interviewees responses reveal that rural private JHS students could not afford to go on excursions and field trips for interactions. Many rural students found it difficult to pay their school fees and buy textbooks. A rural private JHS teacher said: "Paying examination and school fees of children is a problem in the rural area here. Teachers have to sack children to go home and bring their school and examination fees."

Interviewees responses also reveal that rural public JHS students engaged in social and conceptual aspect of inquiry more than urban public JHSs students because rural JHS teachers combined (code-switched) English and the local language during instruction. This facilitated rural students' understandings and encouraged them to participate actively in class discussions and sharing ideas. Rural public JHS teachers combined English and the local language because their students had difficulties reading and understanding English. A rural public JHS teacher said: "English language is a major barrier in teaching science in our rural area here. Teachers bring in the local language before students understand the lessons." Another rural JHS teacher said: "If we use Fante [local language] as the medium of instruction, the students perform very well because they understand the language."

\section{DISCUSSION}

Triangulation of results from the students' and lesson observation ratings and interviewees responses show that inquiry-based science teaching and learning were rarely implemented in the selected Ghanaian JHSs. Instead, traditional science instruction was predominantly implemented. This finding is similar to some past findings in Ghana (Ampiah, 2008; OpokuAsare, 2004) and others in Africa (e.g., Akuma \& Callaghan, 2018; Ramnarain \& Hlatswayo, 2018), but differs from many findings in the industrialised and industrialising countries (e.g., Jiang \& McComas, 2015; Pine et al., 2006; Smith et al., 2007; Tairab \& Al-Naqbi, 2018). Researchers have bemoaned the prevalence of traditional science instruction in African schools in the past (e.g., Anamuah-Mensah, 2012; Shumba, 1999). However, the present finding suggests that implementation of traditional instruction persists in Ghanaian JHSs, despite the emphasis of current curricula rationale for all students to be actively engaged in inquiry investigations (CRDD, 2007, 2012).

Again, while the social aspect of inquiry was considerably implemented in the JHSs, other important aspects (procedural, epistemic, conceptual, and guidance) were rarely implemented. This finding differs from many in the industrialised and industrialising countries (e.g., Chang \& Mao, 1999; Crawford, 2000; Oppong-Nuako et al., 2015). While empirical evidence show several successes and challenges in the implementation of inquiry-based science instruction in many contexts worldwide, including industrialised and industrialising countries, the current finding suggests that Ghana is one of the contexts where implementation of inquiry-based science instruction faces challenges.

Many studies have shown that inquiry-based instruction is more effective than traditional science instruction in promoting students' learning outcomes (e.g., Chang \& Mao, 1999; Furtak et al., 2012; Gillies, 2008; Romero-Ariza et al., 2020). However, the current findings suggest that Ghanaian JHSs continue to implement instructional methods that are less effective in developing students' scientific literacy. Simsek and Kabapinar (2010) and others have shown that students engaged in traditional instruction exhibit low science process skills. The prevalence of traditional instruction in Ghanaian JHSs could be a significant contributor to the inability of JHS graduates to readily apply science process skills in solving problems in real-life experiences.

Again, triangulation of the quantitative and qualitative results show that interaction of school location and school type significantly influenced the implementation of inquiry science teaching and 
learning. Specifically, we found that urban private JHS students engaged in inquiry-based social activities more than rural private JHS students. Urban public JHS students also engaged in fewer inquiry-based procedural activities than urban private JHS students. Although traditional instruction was predominant across all the school types, instructional activities regularly employed in the urban private JHSs led to relative more implementation of inquiry than in rural private and public JHSs. This finding aligns with that of Lederman (1999). In that study, some teachers who had intended to foster students' interests, fun, enjoyment, confidence, positive attitudes toward science, critical thinking, and connection of science to life experiences employed activities that resulted in the implementation of inquiry instruction in their classrooms.

A similar situation may have occurred in the urban private JHSs in this study. Due to the desire and aspirations of urban private JHSs in Ghana to foster students' interests in learning, obtain high pass rates in BECE (external examinations), and increase school enrolment, they employ various activities. These include termly field trips and excursions; some hands-on activities; and regular extra tuition, home works, assignments, mock examinations, and other assessments. These activities may have inadvertently engaged the urban private JHS students in relatively more inquiry-oriented social and conceptual activities; including class discourse, active interactions, sharing of ideas, group work, and knowledge construction. Indeed, Lederman (1999, p. 925) acknowledges that certain traditional "classroom practices and instructional approaches" could be used to achieve inquiry-oriented learning outcomes.

Differences in inquiry-based science instructional experiences between the urban private JHSs on one hand and rural private and public JHSs on the other is largely due to differences in socio-economic backgrounds of the students. Compared to parents of students in rural and public JHSs, many students in urban private JHSs come from parents with higher formal education, more gainful employment, and higher income levels. These parents have the ability to provide sufficient educational materials and funding for their children's educational field trips and excursions, extra tuition at school and home, mock examinations and assessments, home works, and hands-on activities. They show deep interests in their children's learning and expect good academic results for their children (Addy, 2013; Somuah \& Mensah, 2013). In contrast, most parents of students in rural and public JHSs cannot afford to pay for the kind of educational materials and activities available to students in the urban private JHSs. The differences in teaching, learning, and assessment practices between urban private, and public and rural JHSs account significantly for the persistent gaps in science achievements (e.g., BECE results) between students in these schools.

However, empirical evidence shows that when students from diverse socio-economic backgrounds are exposed to sufficient inquiry science instruction, the achievement gaps between them are considerably reduced (e.g., Palinscar et al., 2001). We believe that increased implementation of inquiry science instruction in Ghanaian JHSs is an effective measure to address the persistent gaps in science achievement between urban private, and rural and public JHS students.

We also found that urban public JHS students engaged in fewer inquiry-based conceptual activities than rural public JHS students. Rural public JHS students also engaged in more inquiry-based social activities than urban public JHS students because of code-switching between English and the local language in rural JHSs. This finding is similar to others in the past (Ampiah, 2008; Launio, 2015). Most JHS students and teachers in rural Ghanaian communities speak the same local language of the communities. Therefore, rural JHS teachers have no difficulty employing code-switching between English and the local language to facilitate students' understandings, active discourse in class, construction of meaning, and sharing of ideas in science lessons. In Contrast, many students and teachers in urban and metropolitan JHSs speak many different local languages. This present difficulties for urban JHS teachers to use code-switching between English and any one local language. Therefore, urban JHS teachers tend to rely on English, the common language, for science instruction. This adversely affect the understandings and active class participation of many students who are less proficient in English. Considering the widely acclaimed effectiveness of inquiry teaching and learning in promoting students' achievements (e.g., Furtak et al., 2012), this finding suggests that its' implementation in most Ghanaian JHSs, especially rural and public JHSs, could be feasible if code-switching of English and the local language is actively promoted. Again, while successful implementation of inquiry science instruction in many contexts globally involved students who are proficient or native-speakers of the instructional language, implementation of inquiry in most Ghanaian JHSs may be problematic without the code-switching of English and the students' home language. Integration of code-switching and inquiry science instruction is an effective approach used in many developed countries to promote ELLs' science understanding and English proficiency simultaneously (e.g., Cuevas et al., 2005; Lee, 2005).

\section{CONCLUSIONS}

Findings from this study and others suggest that more needs to be done to reform science teaching and learning in Ghanaian and African schools to align with 
the features of scientific inquiry. Despite the effectiveness of inquiry, findings from this study suggest that its implementation in most Ghanaian schools, especially rural and public JHSs, may be problematic if the official language of instruction is not reconsidered. We hold the opinion that active promotion of codeswitching between English and the home language could enhance the implementation of inquiry in Ghanaian schools, address issues concerning students' science achievements, and promote scientific literacy of junior high school graduates. Findings from this study and others also raise issues about the successes, challenges, and prospects of inquiry-based science instruction in different contexts, especially the African context. We believe that more studies concerning the enactments of inquiry science instruction in actual classrooms in different African settings are required to identify successes, challenges, prospects, and other pertinent matters about this innovative pedagogical approach.

\section{LIMITATIONS}

This study has a number of limitations. First, the relatively small data about code-switching that emerged from interviews with participants limits conclusions that can be drawn about the influence of code-switching in inquiry-based science instruction in Ghanaian JHSs. Separate studies that focus on the processes and impact of code-switching in inquiry-based instruction in the Ghanaian context may yield more data that could result in strong conclusions about the influence of codeswitching.

Second, the focus of much of our data on implementation of inquiry instruction presents limitation in offering reasons for the technical, cultural, and political barriers and dilemmas (Anderson, 1996, 2002) to the slow changes in science teaching and learning in Ghanaian JHSs. Separate studies regarding the technical, cultural, and political barriers and dilemmas of inquiry instruction are required to offer reasons for the slow changes in science teaching and learning in Ghanaian JHSs.

\section{ACKNOWLEDGEMENTS}

We acknowledge the support, guidance, and advise of Professor Damian Kofi Mereku of University of Education Winneba, Ghana in the conduct of this study. We also acknowledge the support of directors and deputy directors of education and head teachers who gave us access into schools and offices to collect data. Additionally, we acknowledge all those who supported us in diverse ways during the data collection.

\section{REFERENCES}

Addy, N. A. (2013). Contextualising the underperformance of rural education in northern Ghana: Management approach. International journal of ICT and management, 1(3), 150-156. Retrieved from https://pds.semanticscholar.org/73f8/9977c68ad a37d7e7e4a55ce64f655e91f48.pdf

Akuma, F. V., \& Callaghan, R. (2019). Teaching practices linked to the implementation of inquiry-based practical work in certain science classrooms. Journal of research in science teaching, 56, 64-90. https:/ / doi.org/10.1002/tea.21469

Ampiah, J. G. (2008). An investigation of provision of quality basic education in Ghana: A case study of selected schools in the Central Region of Ghana. Journal of international cooperation in education, 11(3), 19-37. Retrieved from http:/ / home.hiroshima-u.ac. jp/cice/wp-content/uploads/2014/03/11-3-3.pdf

Anamuah-Mensah, J. (2012). Forward. In A. AsabereAmeyaw, G. J. S. Dei, \& K. Raheem (Eds.), Contemporary issues in African sciences and science education (pp. ix-xii). Sense publishers. https:/ / doi.org/10.1007/978-94-6091-702-8

Athuman, J. J. (2017). Comparing the effectiveness of an inquiry-based approach to that of conventional style in the development of students' science process skills. International journal of environmental and science education, 12(8), 1797-1816. Retrieved from http:/ / www.ijese.net/makale1943

August, D., Artzi, L., \& Mazrum, J. (2010). Improving science and vocabulary learning of English language learners. Retrieved from https://files.eric.ed.gov/ fulltext/ED549174.pdf

Campbell, T., Abd-Hamid, N. H., \& Chapman, H. (2010). Development of instruments to assess teacher and student perceptions of inquiry experiences in science classrooms. Journal of science teacher education, 21(1), 13-30. https://doi.org/10.1007/ s10972-009-9151-x

Chabalengula, V. N., \& Mumba, F. (2012). Inquiry-based science education: A scenario on Zambia's high school science curriculum. Science education international, 23(4), 307-327. Retrieved from https:/ / files.eric.ed.gov/fulltext/EJ1001626.pdf

Chang, C. -Y., \& Mao, S. -L. (1999). Comparison of Taiwan science students' outcomes with inquirygroup versus traditional instruction. Journal of educational research, 92(6), 340-346. https:// doi.org/10.1080/00220679909597617

Chang, Y. -L., \& Wu, S. -C. (2018). A case study on developmental changes of eleventh graders' scientific inquiry competences. Eurasia journal of mathematics, science and technology education, 14(1), 363-382. https:/ / doi.org/10.12973/ ejmste/79838 
Cianciolo, J., Flory, L., \& Atwell, J. (2006). Evaluating the use of inquiry-based activities: Do student and teacher behaviours really change? Journal of college science teaching, 2006, 50-55. https://doi.org/ $10.1002 / \mathrm{tl} .245$

Clegg, J., \& Afitska, O. (2011). Teaching and learning in two languages in African classrooms. Comparative education, 47(1), 61-77. https://doi.org/10.1080/ 03050068.2011.541677

Cohen, L., Manion, L., \& Morrison, K. (2007). Research methods in education (6 ${ }^{\text {th }}$ ed.). Routledge. https:/ / doi.org/10.4324/9780203029053

Crawford, B. A. (2000). Embracing the essence of inquiry: New roles for science teachers. Journal of research in science teaching, 37(9), 916-937. https://10.1002/ 1098-2736(200011)37:9<916::AID-TEA4>3.0.CO;2-2

Creswell, J. W. (2009). Research design: Qualitative, quantitative, and mixed methods approaches ( $3^{\text {rd }}$ ed.). SAGE publications.

Cuevas, P., Lee, O., Hart, J., \& Deaktor, R. (2005). Improving science inquiry with elementary students of diverse backgrounds. Journal of research in science teaching, 42(3), 337-357. https://doi.org/ 10.1002/tea.20053

Curriculum Research and Development Division [CRDD] (2007). Teaching syllabus for integrated science: Junior high school. Author

Curriculum Research and Development Division [CRDD] (2012). National syllabus for integrated science: Junior high school. Author

Estrella, G., Au, J., Jaegi, S. M., \& Collins, P. (2018). Is inquiry science instruction effective for English language learners? A meta-analytical review. https:/ / doi.org/10.1177/2332858418767402

Furtak, E. M., Seidel, T., Iverson, H., \& Briggs, D. C. (2012). Experimental and quasi-experimental studies of inquiry-based science teaching: A metaanalysis. Review of educational research, 82(3), 300329. https:/ / doi.org/10.3102/0034654312457206

Gillies, R. M. (2008). The effects of cooperative learning on junior high school students' behaviours, discourse, and learning during a science-based learning activity. School psychology international, 29(3), 328-347. https:/ / doi.org/10.1177/014303430 8093673

Grigg, J., Kelly, K. A., Gamoran, A., \& Borman, G. D. (2013). Effects of two scientific inquiry professional development interventions on teaching practice. Educational evaluation and policy analysis, 35(1), 3856. https://doi.org/10.3102/0162373712461851

Hansen, B., \& Buczynski, S. (2013). The teaching of inquiry-based science in elementary classrooms: A bi-national comparative reflection of US and Lithuanian practices. International journal of higher education, 2(3), 41-53. https://doi.org/10.5430/ ijhe.v2n3p41

Jacob, S. A., \& Furgerson, S. P. (2012). Writing interview protocol and conducting interviews: Tips for students new to the field of qualitative research. The qualitative report, 17(6), 1-10. Retrieved from https://nsuworks.nova.edu/tqr/vol17/iss42/3

Jantjies, M., \& Joy, M. (2015). Mobile enhanced learning in a South African context. Journal of educational technology $\mathcal{E}$ society, 18(1), 308-320. Retrieved from https://www.jstor.org/stable/jedutechsoci.18.1.3 08

Jegede, O. J. (1993). African cultural perspectives and the teaching of science. Retrieved from https:/ / files.eric. ed.gov/fulltext/ED365526.pdf

Jiang, F., \& McComas, W. F. (2015). The effects of inquiry teaching on student science achievement and attitudes: Evidence from propensity score analysis of PISA data. International journal of science education, 37(3), 554-576. https://doi.org/10.1080/ 09500693.2014.1000426

Launio, R. M. (2015). Instructional medium and its effect on students' mathematics achievement. International journal of multidisciplinary current research, 3, 462-465. Retrieved from http:/ /ijmcr.com/wp-content/uploads/2015/05/ paper12462-465.pdf

Lederman, N. G. (1999). Teachers' understanding of the nature of science and classroom practice: Factors that facilitate or impede the relationship. Journal of research in science teaching, 36(8), 916-929. https:/ / doi.org/10.1002/(SICI)1098-2736(199910) 36:8<916::AID-TEA2>3.0.CO;2-A

Lee, O. (2005). Science education with English language learners: Synthesis and research agenda. Review of educational research, 75(4), 491-530. https:// doi.org/10.3102/00346543075004491

Lee, O., \& Buxton, C. (2013). Integrating science and English proficiency for English language learners. Theory and practice, 52(1), 36-42. https:/ / doi.org/10.1080/07351690.2013.743772

Leon, M. R. (2012). Introduction of inquiry-based science teaching in Rwandan lower secondary schools: Teachers' attitudes and perceptions (Doctoral dissertation, University of Kwazulu-Natal, Durban, South Africa). Retrieved from https://pdfs.semantic scholar.org/faf1/93f37f5e9c6ffb942c8fff00d71f2a6f edb9.pdf

Macaro, E., \& Lee, J. H. (2013). Teacher language background, code-switching, and English-only instruction: Does age make a difference to learners' attitudes? TESOL Quarterly, 47(4), 717-742. https://doi.org/10.1002/tesq.74

Mamombe, C., Mathabathe, K. C., \& Gaigher, E. (2020). The influence of an inquiry-based approach on 
grade four learners' understanding of the particulate nature of matter in the gaseous phase: A case study. Eurasia journal of mathematics, science and technology education, 16(1), 1-11. https://doi.org/ 10.29333 / ejmste/110391

National Research Council [NRC] (1996). National science education standards [NSES]. National academy press. Retrieved from https://www.csun.edu/ science/ref/curriculum/reforms/nses/nsescomplete.pdf

Opoku-Asare, N. A. A. (2004). Non-book instructional materials usage in Ghanaian primary schools. Journal of Science and Technology, 24(2), 106-115. https:/ / doi.org/10.4314/just.v24i2.32922

Oppong-Nuako, J., Shore, B. M., Saunders-Stewart, K. S., \& Gyles, P. D. T. (2015). Using brief teacher interviews to assess the extent of inquiry in classrooms. Journal of advanced academics, 26(3), 197 226. https:/ / doi.org/10.1177/1932202X15588368

Palinscar, A. S., Magnusson, S. J., Collins, K. M., \& Cutter, J. (2001). Making science accessible to all: Results of a design experiment in inclusive classrooms. Learning disability quarterly, 24(1), 15-32. https:/ / doi.org/10.2307/1511293

Pine, J., Aschbacher, P., Roth, E., Jones, M., McPhee, C., Martin, C., Phelps, S., Kyle, T., \& Foley, B. (2006). Fifth graders' science inquiry abilities: A comparative study of students in hands-on and textbook curricula. Journal of research in science teaching, 43(5), 467-484. https:/ / doi.org/10.1002/tea.20140

Ramnarain, U., \& Hlatswayo, M. (2018). Teacher beliefs and attitudes about inquiry-based learning in a rural school district in South Africa. South African journal of Education, 38(1), 1-10. https://doi.org/ 10.15700/saje.v38n1a1431

Romero-Ariza, M., Quesada, A., Abril, A. M., Sorensen, P., \& Oliver, M. C. (2020). Highly recommended and poorly used: English and Spanish science teachers' views of inquiry-based learning (IBL) and its enactment. Eurasia journal of mathematics, science and technology education, 16(1), 1-16. https:/ / doi.org/10.29333/ ejmste/109658

Sassenrath, J., Croce, M., \& Penaloza, M. (1984). Private and public school students: Longitudinal and achievement differences. American educational research journal, 21(3), 557-563. https://doi.org/ $10.3102 / 00028312021003557$

Shumba, O. (1999). Critically interrogating the rationality of western science vis-à-vis scientific literacy in nonwestern developing countries. Zambezia, xxvi (i), 5575. Retrieved from https://pdfs.semanticscholar. org/e4d8/974930943468ac677418d323af4ab1b8b24 9.pdf
Silva, C., \& Kucer, S. (2016). Into the field: Learning about English language learners in newcomer programs. Journal of inquiry $\mathcal{E}$ action in education, $8(1), 1-22$. Retrieved from https: / / files.eric.ed.gov / fulltext/EJ1133592.pdf

Simsek, P., \& Kabapinar, F. (2010). The effects of inquirybased learning on elementary students' conceptual understanding of matter, scientific process skills, and science attitudes. Procedia - social and behavioural sciences, 2, 1190-1194. https:/ / doi.org/10.1016/j.sbspro.2010.03.170

Smith, T. M., Desimone, L. M., Zeidner, T. L., Dunn, A. C., Bhatt, M., \& Rumyantseva, N. L. (2007). Inquiryoriented instruction in science: Who teaches that way? Educational evaluation and policy analysis, 29(3), 169-199. https:/ / doi.org/10.3102/0162373707306025

Somuah, B. A., \& Mensah, F. (2013). Science teaching, science teachers: Differences in challenges of urban and rural teachers. Journal of education and practice, 4(19), 22-27. Retrieved from https:/ / pdfs.semantic scholar.org/0be3/a0be12e6e1ddaf1c5e55e20e0aff1 403cf73.pdf

Ssempala, F. (2017). Science teachers' understanding and practice of inquiry-based instruction in Uganda (Doctoral dissertation), Syracuse University, Syracuse, NY. Retrieved from https:/ / surface.syr.edu/cgi/viewcontent.cgi?artic le $=1690 \&$ content $=$ etd

Suhr, D. D. (2006, March). Exploratory or confirmatory factor analysis? Paper presented as SAS users group international conference (SUGI 31), San Francisco, CA. Retrieved from https://support.sas.com/ resources/papers/proceedings/proceedings/sugi 31/200-31.pdf

Tairab, H., \& Al-Naqbi, A. (2018). Provision of inquiry instruction and actual practices as perceived by science teachers and their students. Eurasia journal of mathematics, science and technology education, 14(1), 397-412. https:/ / doi.org/10.12973/ejmate/80320

Van Aalderen-Smeets, S., \& Walma van der Molen, J. (2013). Measuring primary teachers' attitudes toward teaching science: Development of the dimensions of attitude toward science (DAS) instrument. International journal of science education, 35(4), 577-600. https://doi.org/10.1080/09500693. 2012.755576

Wolf, S. J., \& Fraser, B. J. (2008). Learning environment, attitudes, and achievement among middle-school science students using inquiry-based laboratory activities. Research in science education, 38, 321-341. https:/ / doi.org/10.1007/s11165-007-9052-y

\section{http://www.ejmste.com}

